\title{
Александар Милановић
}

\section{АКТУЕЛНОСТ ВУКОВИХ РАНИХ ПОГЛЕДА НА ФОНЕТСКО-ФОНОЛОШКИ САСТАВ СРПСКОГ КЊИЖЕВНОГ ЈЕЗИКА (1814-1818)}

\begin{abstract}
Прихватајући од 1814. Аделунгов принцип „пиши као што говориш”, Вук је већ у првој фази стваралаштва пуно пажње посветио инвентару гласова и фонема у будућем српском књижевном језику. Анализа Вукових формулација при навођењу инвентара показала је да је непосредно пред појаву Српског рјечника предложени фонетско-фонолошки систем српског језика, према интегрисаности и фреквенцији јединица у источнохерцеговачким говорима, имао следећу структуру: $27+1+2$. У њему је делимично маркирана фонема /џ/, док су сасвим обележене фонеме / $/$ / и /x/. У питању је несумњива еволуција Вукових научних сазнања, будући да је првобитни модел из Писменице српског језика имао структуру $27+2$, са издвојеним статусом фонема /ф/ и /х/, а без фонеме /џ/.
\end{abstract}

Кључне речи: Вук Стефановић Караџић, Писменица српског језика, фонема /ф/, фонема /x/, фонема /џ/, вокално /л/, вокално /p/, нормирање српског језика.

1. Добро је познато да се Вуково научно стваралаштво развијало: да су његови методи еволуирали, знање и искуство расло, а критеријуми постајали чвршћи и прецизнији. Сви најзначајнији истраживачи Вуковог стваралаштва који су тежили синтезама, међу којима су у два наврата били и приређивачи Вукових сабраних дела, прихватили су периодизацију коју је још крајем 19. в. предложио Армин Павић, а којој је дефинитиван лик дао Пера П. Ђорђевић (Николић 1968: 389, Павић 1986: 645). Према наведеним периодизацијама, прву од три целине чине Вукови списи из периода 1814-1818, тј. до појаве Српског рјечника.

Иако је и о овоме периоду Вуковога стваралаштва јако много писано, додуше неупоредиво мање но о друга два, чини се да недостаје више радова који представљају покушаје систематизације тј. синтезе раних Вукових филолошких погледа. Стога ће овај рад управо из те перспек- 
тиве сагледати Вукове ставове о фонетско-фонолошком саставу српског књижевног језика у периоду када је још увек лутао у филолошким решењима, тражећи поуздане критеријуме кроз анализу постојеће литературе, али и кроз анализу српске језичке ситуације.

2. Будући да графија, ортографија и фонетика почетком 19. в. у радовима српских језикословаца још увек методолошки нису биле довољно раздвојене, у судове о фонетско-фонолошком саставу српског књижевног језика неопходно је улазити пре свега кроз анализу графијских и ортографских начела којих су се држали, а потом и преко истраживања непосредних а ређих ставова о статусу појединих гласова у говору или књижевном језику. По Копитаревој сугестији, централни ортографски принцип који на почетку Вук прихвата Мркаљевим посредством, био је Аделунгов мото „пиши као што говориш”. Он је подразумевао регистровање гласовних алтернација на морфемским спојевима, односно начело да једној фонеми одговара једна графема у писању. Мркаљ га је увео у српску филологију - не применивши га нигде у своме стваралаштву кроз кратку и узгредну напомену на самом крају, тј. на 18. страни Сала дебелога јера („От данас све наше правописаније под ово долази начало: Пиши како што говориш."). Одјек Мркаљеве правописне сугестије видљив је већ у Вуковој рецензији Новина српских, где додуше не критикује нерегистровање алтернација на морфемским границама већ писање множинског облика „тужителе” место облика „тужителъ”, али кроз формулацију са видљивом парафразом Мркаљевих и Аделунгових речи: „Пак зашто дасе ръчи изврћу, и да се другчіе пишу него што се говоре?” (Караџић 1968: 17). У Писменици српскога језика (1814) Вук је већ проширио и прецизно формулисао своје „заглавље”, указујући да је свестан снаге критика које следе због револуционарног захвата у писању:

Перва и наївећа критика, коїа ће срести ову моїу Писменицу, бит' ће сверху начина правописаньа: и їа сам истина о овоме много сумньао и размисльавао, но наїпосле ми се учинило да їе овако наїлагше дотерати Сербско Правописанье под оно заглавлье: Пиши, као што говориш; а читаї, као што їе написано” (Караџић 1968: 31).

Међутим, иако попут Мркаља предлаже фонетски (фонолошки) принцип у писању, ни Вук га као ни Мркаљ неће спровести у дело нити у Писменици нити у другим радовима све до Српског рјечника (1818), када коначно напушта морфонолошки ортографски проседе.

3. Уколико се и сасвим површно анализира инвентар графема који у Писменици предлаже вођен начелом „пиши као што говориш”, јасно се уочава да је Вук у првобитним фонетско-фонолошким решењима био 
ближи погледима Саве Мркаља него онима Луке Милованова Георгијевића. ${ }^{1}$ Док је, наиме, Милованов 1810. у рукопису Опита наставлена $\kappa$ српској сличноречности предлагао ћирилицу од 30 графема, укључујући и решење за фонему /џ/ (Милановић 2013: 191-193), Мркаљ је исте године у Салу дебелога јера штампао и предлог српске ћирилице од 29 јединица, без помена фонеме /џ/ и одговарајуће графематске реализације (Милановић 2011). Питању Вуковог првобитног језикословног узора и разлозима који га воде ка инвентару од 29 графема у постојећој литератури није посвећена одговарајућа пажња.

Чак и када су анализирали предложени инвентар графема у Вуковој реформисаној ћирилици из Писменице, многи веома значајни истраживачи уопште нису проблематизовали статус гласа и фонеме /џ/ у њој, полазећи само од чињенице да је, нпр. „показао много дара и за даље усавршавање доста савршене Мркаљеве азбуке” (Стевановић 1988: 17), при чему се мислило на одстрањивање диграфа. Поједини истакнути србисти, попут Михаила Стевановића, проблем са фонемом /џ/ су на другом месту само уочили, не покушавајући да га реше. ${ }^{2}$ Међутим, ваља подвући да је подстицај за увођење фонеме /џ/ Вук могао добити и из научне литературе: како је 1814. већ имао Миловановљев рукопис, ${ }^{3}$ несумњиво је био у прилици да бира између два предложена графијска и фонетско-фонолошка система, са 29 или 30 јединица.

Избору Мркаљевог предлога за инвентар књижевног језика несумњиво су допринеле и Копитареве сугестије везане за избор графије (Стојановић 1924: 91), али је пресудан био Вуков тадашњи пуристички однос према турцизмима, сасвим видљив већ у необјављеној рецензији

${ }^{1}$ Овиме се готово директно може одбацити и претпоставка, злонамерно ширена још од времена Јована Хаџића, да је аутор Писменице заправо био Лука Милованов. Уп. и Поповићево мишљење о коауторству: „Вук и Лука Милованов састављали су своју граматику" (Поповић 1987: 70). Морамо се сложити са Љубомиром Стојановићем да „што је узео од Луке теже је одредити” (Стојановић 1924: 78).

2 „Вук је пре него што је почео писати морао чути у народу речи с гласом $u$, ма и не биле оне домаћег порекла. Такве речи срећемо не само у његовој Песнарици већ и и у личним објашњењима испод текста песама, тј. у његову личном језику, па се зато с правом питамо зашто Вук о томе није водио рачуна када се опредељивао за једну азбуку, већ је једноставно у Писменици дао образложење да тога гласа нема у народним речима" (Стевановић 1987: 69).

${ }^{3}$ О судбини Миловановљеве књиге Вук у њеном предговору износи: „Године 1814. у пролеће саставши се ја с њим у Будиму, и разумевши за историју њену, намолим га, да је да мени, да је о свом трошку штампам у Бечу." 
Новина српских. У њој Вук критикује уреднике за активирање турцизама јуриш и капија управо због порекла лексема (Караџић 1968: 16). Вероватно и под утицајем Мркаљевог пуризма (Милановић 2011), и Вук је 1814. желео протерати стране, махом турске речи из будућега српског књижевног језика, нудећи као алтернативу чак и славенизме. Будући да упркос прокламованом још увек задржава морфонолошки ортографски проседе, ни Вуку, као ни Мркаљу, још увек није било потребно графематско решење за фонему /џ/ у ретким речима домаћег порекла.

Веома јак аргумент у прилог нашој наведеној тези представља са̂м Вуков тадашњи језик у филолошким радовима: у њему нема домаћих речи типа наруцбина или свједоцба, у којима је /џ/ добијено једначењем по звучности, а и турцизми са овом фонемом су више него ретки. Усамљени пример из Писменице налази се у посвети: вальале по бучжацима (Караџић 1968: 27). И каснији примери, нпр. из рецензије Видаковићевог Усамљеног јуноме или Одговора на Палинодију, или обрану дебелога јера, указују да је Вук још увек примењивао једно од традиционалних решења из славеносрпске ћирилице - иако је у питању диграф - за ретке турцизме: у Мачжарской (Караџић 1968: 129, 130), беле чжигерице (135), читавъ чжелепъ (138), начжакбабе (147), ракичжїя (193), ракичжїинъ (193), ракичжїйница (193). ${ }^{4}$ Сасвим неправедно, Вук је 1817. чак осуђивао Мркаљево графематско решење за /џ/, не нудећи нимало боље и некоректно пребацујући проблем са графијско-ортографског на фонетско-фонолошки терен: Србльи не говоре жигерица, него чжигерица (Караџић 1968: 140). Чини се, међутим, да је и кроз читање српских научних, публицистичких и белетристичких дела Вук све више увиђао неопходност увођења нове графеме за сасвим уобичајене речи у српском народном језику, па тако у другој рецензији Видаковићевих романа више не критикује пишчев избор турцизама (са фонемом /џ/), већ његову графијско-ортографску недоследност: „Ево како наблюдава точность, и како се држи своїе правила: (...) жепъ (Ч. I, 183) джепъ (Ч. II 152) дчепъ (Ч. II 197) чебъ (Ч. II 57)” (Караџић 1968: 191-192). Вук тако принцип „пиши као што говориш” већ почиње комбиновати са правилом „опћене правилности”, другим кључним у својој реформи, које ће на важности у нормирању граматичке структуре књижевног језика посебно добити тек у његовој трећој фази стваралаштва.

4 Уп. и касније примере: Мачжарской $(181,192)$, ракичжија (193). Стевановићеву претпоставку да Вук употребљава и диграф <дж> ваља одбацити, јер у примерима само цитира Видаковићеве оригиналне графематске облике, што и сам аутор примећује (Стевановић 1987: 69-70). 
У Одговору господину -Ц-, упућеном заправо Платону Атанацковићу 1818, Вук уводи и графему <џ>, уз напомену у фусноти која се односи на специфичан статус ове фонеме према критеријумима порекла и фреквенције: „Ово је истина понайвише за тудье речи, али се чуе гдешто и у нашим речма, н. п. увеџбати, сведоџба, наруџбина и т. д." (Караџић 1968: 232). Да се Вук још увек колебао око статуса нове графеме чак и у Српском рјечнику, потврђују дублети типа наруибина/наручбина или свједочба/свједочба (Ивић 1991: 57, Кашић 1987: 22).

4. Графему $<\mathrm{x}>$ из грађанске ћирилице Вук је навео међу „29 писмена" у Писменици, али њу, као и графеме $<\mathrm{i}>$ и $<\phi>$, прати и специфична „примиједба":

„Писме х Сербльи прости верло тежко изговараїу; него или га са свим изоставе н. п. Христос, хоћу, орах, они говоре: Ристос, оћу, ора; или га промїене у друго какво писме, а особито у в и к н. п. сухи, жених, они говоре суви, женик. А Сербльи по Херцеговини и по Церної Гори у глаголима у времену прошавшем простом 2ом промїеньуїу га у г н. п. убих, видїех, наїдох, они говоре: убиг, видьег, надьог, додьог и пр. Зато ово писме х кад стоїи у почетку пред самогласним писменом, или у среди медьу два самогласна, онда се може у Сербскоме їезику изоставити н. п. хоћу, маховина, духовник, може се писати: оћу, маовина, дуовник” (Караџић 1968: 39).

Две се битне напомене морају ставити у вези са наведеним цитатом. Прва се односи на детаљ у којем Вук придевом истиче како овај глас само „Србљи прости врло тешко изговарају”, не експлицирајући који су они који га изговарају. За потпуно разумевање овог Вуковог исказа, неопходно је упоредити га са одговарајућим Мркаљевим из Сала дебелога јера на стр. 12, у којем Вуков претходник каже: „За х сељани Србљи не знаду; но мало уљуднији почти свагда га изговарају, и ја га зато употребљавам". Уколико из контекста можемо реконструисати да су за Мркаља „мало уљуднији" Срби који чувају /x/ они образованији, што живе по градовима, уочљиво је да Вук и 1814. осећа пуристичку одбојност према урбаним говорима, сматрајући их исквареним због страних утицаја, па их зато и не спомиње. ${ }^{5}$

Друга напомена тиче се чињенице да Вук, упркос прећуткивању информација о стању у градским говорима Срба, дозвољава у Писменици дублетне форме типа хоћy/ohy, маховина/маовина или духовник/дуов-

5 Повратак градским говорима као корпусу при стандардизацији језика уследиће тек у фази реконструкције норме, током 1836. и 1839. године. 
ник. ${ }^{6}$ И не само да их дозвољава, већ у читавој граматици, уз доста недоследности, пише графему $<\mathrm{x}>\mathrm{y}$ етимолошком положају, чак и на многим местима на којима је више неће бити у Српском рјечнику. ${ }^{7}$ Посебно је значајно утврдити присуство ове фонеме и графеме у конјугацијским наставцима, али и у узвицима типа $а x !$ и ох! (Караџић 1968: 111).

Управо увидевши при писању Писменице (не)системност морфолошких парадигми без присуства /x/ у њима, Вук је предложио и враћање етимолошком принципу, чиме је најавио будући принцип „опћене правилности”, као и његову примену у реконструкцији из 1836:

„Или, могло би се учинити, да се пише свуда, гди се год у Славенском їезику [рускословенском језику - прим. А. М.] находи, али да се неизговара твердье него Ньемецко h без с; и на таї начин могло би нам (х) на много мїеста од велике потребе и од помоћи бити" (Караџић 1968: 39).

Иако на наведеној страни Писменице експлицитно не каже која су то места и каква је то помоћ, само петнаестак страна касније Вук при опису морфолошке парадигме именице снаха указује у фусноти на проблем: „Ово х код Сербальа слабо се у оваким риечма чути може, него се каже снаа, а у дат. говоре и снаи, и снаси" (Караџић 1968: 49). Наведене проблеме везане за регуларност парадигми Вук је решио реформом из 1836, када враћа фонему /x/ у етимолошком положају.

5. Међу 29 графема из грађанске ћирилице предвиђених за српски књижевни језик у Писменици нашла се и графема $<\phi>$, уз одговарајућу фусноту: „Писме ф само їе за тудье риечи, а Сербске ни їедне риечи неїма гди би ово требало; и зато га прости Сербльи у говору, свуд готово, промїеньуїу на в" (Караџић 1968: 39). И овде је препознатљив Мркаљев утицај, који је већ у Салу дебелога јера констатовао да „ф је за стране ријечи". На сличан начин у Опиту функцију графеме $<\phi>$ описује и Милованов: „Ф двадесет девето писме, чинисе за туђе речи нуждно”.

Значајно је истаћи две чињенице у вези са статусом фонеме /ф/ и Писменищи: а) на наведеном месту Вук не нуди нити један пример за супституцију /ф/ > /в/, ${ }^{8}$ што чини у парадигматској ситуацији када објашња-

${ }^{6}$ Вук се много колебао око статуса фонеме /x/, па се о томе „саветовао с Мушицким и Гершићем” (Стојановић 1924: 134). Мушицки је био за чување графеме $<\mathrm{x}>$, док је Гершић „био за то да се $x$ и $\oint$ избаце, јер их српски народ не изговара" (Стојановић 1924: 135).

7 Уп. нпр. фонетске и графијске ликове речи Херцеговина и сл.

8 Уп. нпр. Вукове облике: не чини вайде (Караџић 1968: 139), филозови (206). 
ва судбину фонеме /x/, а уопште не помиње супституцију /ф/ > /п/; б) у читавој граматици, нити у основном тексту нити међу примерима, нема нити једне речи са овом фонемом, не рачунајући имена и звања претплатника: Стефан, философие Доктор (Караџић 1968: 117). За разлику од потврда за /x/, фонеме /ф/ нема нити међу примерима за узвике (нпр. * $y \oint$ или сл.). У каснијим радовима позајмљенице са фонемом / $/$ су ретке, а по пореклу из различитих језика, па се у њима препознају грчки и турски, али и новији утицаји на српски језик: Французи (Караџић 1968: 135, 136), Аристофана (136), Филозофи (147), порфира (147), Филипъ (148), Физику (159), арфу (166), официра (167), калфе (167), Фелдмаршалу (168), Францускїй (168), Фамилїомъ (169), Флоренцїи (181), Графомъ, орөографїе (214).

На основу ових података видљиво је да је Вук у почетку био веома опрезан када је статус / $/$ / к кижевном језику у питању, опрезнији чак и у односу на проблем са фонемом $/ \mathrm{x} / .^{9}$ Опрез је произлазио из статуса ове фонеме у тршићком говору, где је углавном била супституисана фонемом /в/, као и Вуковим резервисаним ставом према градским говорима. ${ }^{10}$ И са̂м Јернеј Копитар није био задовољан Вуковим образложењем и примерима у вези са фонемом /ф/ (Стојановић 1924: 89).

6. Почетком 19. в. у младограматички оријентисаној славистици решаван је и статус вокалног /л/, што је оставило трага и на расправе о фонетско-фонолошком саставу будућег српског књижевног језика. У другој рецензији Видаковићевих романа Вук се осврнуо на ставове Добровског: „Осимъ тога їоштъ бы Г. Добровскій (колико га мы познаемо изъ свїю нбговы кньига) радъ быо, да се пише у нъговоме среднъмъ слогу, слза, слнце” (Караџић 1968: 198). Како се појам „средњег слога” тј. средњег стила односио у актуелној српској језичкој ситуацији на доситејевски славеносрпски језик, конкурента чистом народном језику у Вуковој концепцији, будући реформатор је осетио потребу да реагује у фусноти: „Ово бы добро было за Бугаре: зашто они и данасъ говоре слнце, жлтица, влкъ, длгъ и т. д." (Караџић 1968: 198). Региструјући вокално /л/ само у бугарским народним говорима, Вук се огрешио о стање у

${ }^{9}$ Колебања око статуса графема видљива су била и у Српском рјечнику. „Пажљиви читалац уочиће разлику између Вуковог списка српских слова на почетку Српске граматике (стр. XXIX) и оног на крају (стр. LXIX). Овај други списак садржи и три слова којих нема у првом. То су $b, \oint$ и $x$ " (Ивић 1991: 54).

${ }_{10}$ Тек у Српском рјечнику Вук напомиње да се овај глас чује у градским говорима, а касније га је могао чути и у другим народним говорима, па га је постепено стабилизовао - уп. фусноту 8 у Ивић 1991: 55. 
српским дијалектима: у почетку свога језикословља он није могао знати стање у призренско-тимочком вокализму.

Приписивање вокалног /л/ искључиво бугарском вокализму Вук је поновио и у Одговору господину -u-: „глбина (као што Бугари и данас говоре и читају)" (Караџић 1968: 229). Како вокалног /л/ није било у источнохерцеговачком дијалекту, као ни у писаној доситејевској традицији, оно је остало сасвим ван интересовања Вукових, али и Мркаљевих и Миловановљевих.

7. Препознавши специфичан статус фонеме, Вук је увео и диграф $<\mathrm{pъ}>$ за обележавање вокалног /p/ испред вокала. Исти проблем уочио је и Мркаљ у радовима објављеним 1817, после Сала дебелога јера (Окука 2010: 79-80), па је за ту позицију и предложио диграфско решење са дебелим јером <ръ>. У Одговору на Палинодију, или обрану дебелога јера Вук је као битан критеријум у анализи опет изнео фреквенцију: „Само оне неколике речи (гръоце, връови, умръо, сатръо и т. д.) могле су доказати да намъ треба ъ” (Караџић 1968: 138). Да овакво графематско решење доприноси разјашњењу слоговне структуре речи, тврдио је и Вук, указавши и на сопствено графематско решење и опет се вративши питању учесталости облика:

„И тако е постало гръоце (троесложно; гр-о-це); а да не бы то ко могао читати двоесложно (гро-це), метнуто е (у второй части народне Србске пъсмарице, на стр. 158. у 2рой врсти одозго) измедьу р и о ъ, да се зна да оно о не принадлежи къ слову р, него да е само гр за себе слогъ, као и на више мъста у нашемъ езыку н. п. грнути, гртанье и т. д. - Нека не мысли Г. Меркайль да оно ъ овде значи друго штогод, него е метнуто само да растави р и о. И у таковомъ случају нужно намъ е ъ само кодъ слова р, а особито кодъ неки глагола у прошавшемъ времену н. п. умръо, сатръо, подупръо, навръо, подувръо и т. д. Може быти да у целомъ нашемъ езыку нема 10 речїй где бы морали писати ъ место х (и то све кодъ р) као н. п. връови, скръати и т. д." (Караџић 1968: 139).

У Другој рецензији Видаковићевих романа Вук је, следећи оправданост истицања специфичног фонолошког статуса, писао: што е умръо у Земуну (Караџић 1968: 171). ${ }^{11}$ Ово решење Вук је доследно бранио и у Одговору господину -u-:, понављајући изнесену аргументацију и водећи рачуна и о „опћеној правилности” свога графематског решења:

${ }^{11}$ Исти графематско-ортографски принцип Вук је задржао и у Српском рјечнику (Ивић 1991: 54). 
„Я бы рекао да ъ задржимо у среди у онымъ речма, где е р слогъ, а предъ ньимъ, или за ньимъ, стои самогласно слово, н. п. сатръо, умръо, гръоце, заръзати и т. д. Г. -ц- каже да ће писати вр'ом; айде да му и то допустимо, као да е изоставль но х, али како ће писати сатръо, умръо, гръоце и т. д.? Овде не може апостроф метнути" (Караџић 1968: 230).

Новину је сада представљао Вуков предлог да се диграф пише и у позицији вокалног /p/ иза вокала, тј. префикса који се њиме завршава, као у примеру заръзати. ${ }^{12}$

8. У домаћим речима Вук је одбацивао писање руске и рускословенске графематске секвенце <ер> на месту вокалног /p/, замерајући Добровском што предлаже „тако исто перстъ, а не ће прстъ, кое е и Србски и Славенски!” (Караџић 1968: 198). Предложено графематско решење, $<\mathrm{p}>$ за вокално /p/ у интерконсонантском положају, Вук у домаћим речима није доследно примењивао, вођен ортографским конзервативизмом тј. доситејевским славеносрпским наслеђем (уп. већ наслов Писменица сербскога їезика). ${ }^{13} \mathrm{C}$ временом стабилизује у писању облике у складу са народним фонетизмом, које добро илуструју примери са само две стране из Одговора господину -й-:, Мркаля, дрляти, рдьаво (Караџић 1968: 230-231).

9. Увођење рускословенског у функцију књижевног језика код Срба у 18. в. покренуло је и питање изговора вокала јери, које је као нерешено наслеђено и у славеносрпском језику. Иако га од средине 13. в. није било ни у једном српском дијалекту, иако се Константин Костенечки у Сказанију о писменех на почетку 15. в. жалио да га Срби и у српскословенском језику изговарају као вокал /и/, вокал јери враћао се као књижевнојезички проблем и почетком 19. в., па је Вук осетио обавезу да одговори на Мркаљев предлог из Палинодије „да ы треба изговарати као што Немцы изговараю свое ӥ” (Караџић 1968: 135). Вук одговара јасно и језгровито, нудећи уз фонетско-фонолошку опсервацију и графематско решење за јери у етимолошком положају:

12 О Вуковим дилемама како обележити вокално /p/ иза вокала у Српском рjечнику в. фусноту 6 у Ивић 1991: 54-55.

13 Михаило Стевановић је претпостављао и да су појединци изговарали / ер/ на месту графематске секвенце, подвлачећи да је у Писменици неупоредиво више речи „у којима Вук тај глас пише двословним знаком -ер, онако, дакле, како су га писали дотадашњи књижевници, па, и они лично, а и сви који су били или се правили учени, тако и изговарали" (Стевановић 1987: 68). 
„Да е рекао да су га (т. е. ы) некадъ изговарали некаквы люди као Немачко ӥ, и то му не бысмо сви веровали, а камоли, да га садъ почнемо мы изговарати. Не треба нъга (ы) кодъ насъ изговарати (нити се може), него као и; и зато може свакїй слободно и писати место ы, као што и чине готово сви Србљи, кои пишу, особито трговцы” (Караџић 1968: 136-137).

Из наведеног Вуковог цитата може се наслутити да је српско свештенство и почетком 19. в. инсистирало на посебном изговору јерија и у доситејевском језику, а вероватно се то односило и на део грађанске интелигенције. Вук, сасвим очигледно, ни пре Српског рјечника није рачунао на ову фонему и глас у будућем књижевном језику, заснованом на народној основи. ${ }^{14}$

10. Уместо закључка, могли бисмо се поново вратити Вуковим синтетичким погледима на проблем фонетско-фонолошког инвентара у српском књижевном језику. Он је у Писменици српског језика Мркаљеву црквену ћирилицу заменио грађанском, остављајући у њој 29 графема, без диграфа:

„Сад наша Азбука, или како прости Сербльи по Сербиїи и по Херцеговини говоре, Буквица, има 29 писмена, медьу коїима ни їедно ни їе сувише, ни їедно звукопремїенльиво, нити коїе недостаїе, него и їе таман онолико, колико своїство Сербског їезика изискуїе" (Караџић 1968: 38).

Исти проблем нешто касније, у тексту Одговор господину -и-, имао је другачије решење, што је још увек сведочило о Вуковим лутањима у одговору на једно од круцијалних књижевнојезичких питања код Срба:

„Совершена азбука може быти само она, коя има онолико просты слова, колико у езыку има просты гласова (Laut); тако да свакїй простакъ, кои за неколика дана научи читати и писати, може цео свой векъ тако правилно писати, као найвећїй Аделунгъ; [...] У Србскомъ езыку има 28 просты гласова, кои се за садъ могу овако записати” (Караџић 1968: 232).

У Вуковом инвентару сада је већ била и графема $<џ>$ делимично издвојена напоменом у фусноти коју смо навели у т. 3 овога рада, а сасвим издвојен статус у односу на графеме за „наши 28 гласова” добијају графе-

${ }_{14}$ Вуку је и Павле Соларић саветовао да задржи графему <ы> (Стојановић 1924: 133). 
ме $<\phi>$ и $<\mathrm{x}>$ : „ф и х то е само за тудье речи, и задржаћемо и” (Караџић 1968: 232). Очито је да је током читавога првог периода стваралаштва Вуку кључни проблем представљао статус фонема које су се у том периоду јављале углавном у структури позајмљеница - /џ/, / $/$ / и /х/.

Проблем фонетско-фонолошког инвентара Вук није могао решити без осмишљене концепције будућега српског књижевног језика, а због језичке ситуације једно од кључних питања у њој морало је бити везано за статус позајмљеница. Будући да се Вук у својим језикословним размишљањима кретао од првобитне пуристичке концепције из рецензије Новина српских, која је подразумевала протеривање турцизама и толерантан однос према славенизмима, ка новој, толерантној према турцизмима а строгој према славенизмима, одраз нестабилизоване концепције књижевног језика видљив је и у инвентару и статусу фонема и графема.

Маргиналне проблеме, везане за фонетско-фонолошки статус вокалног /л/, вокалног /p/ и јерија, Вук је решио до објављивања Српског рјечника у складу са стањем у народним говорима које је у том тренутку познавао.

И суштаствене и маргиналне проблеме Вук је решавао у складу са Аделунговим начелом „пиши као што говориш”, полазећи од стања у народним говорима које је у том тренутку познавао. Главни критеријуми при одређивању фонетско-фонолошког статуса јединица били су му њихово порекло и фреквенција у живоме народном језику, пре свега источнохерцеговачком дијалекту, а и пре Српског рјечника определио се за систем од 30 јединица, у којем су само графеме, фонеме и гласови $\oint$ и $x$ имали посве издвојен статус, док је $u$ већ постало мање обележено: у систем је уведено због потврђености у домаћим речима, али ипак као маркирано због малог броја и ниске фреквенције таквих лексема.

Стога пажљива анализа Вукових формулација показује да је непосредно пред појаву Српског рјечника предложени фонетско-фонолошки систем српског језика, према интегрисаности и фреквенцији јединица у источнохерцеговачким говорима, заправо имао следећу структуру: 27 $+1+2$, у којем је делимично маркирана фонема /џ/, док су сасвим обележене фонеме /ф/ и /х/. У питању је несумњива еволуција Вукових научних сазнања, будући да је првобитни модел имао структуру $27+2$, са издвојеним статусом фонема /ф/ и /x/, а без фонеме /џ/. 
ИЗВОР

Караџић 1968: Вук Стефановић Караџић, О језику и кюижевности I, Сабрана дела Вука Караџића, књига дванаеста, Београд: Просвета.

\section{ЛИТЕРАТУРА}

Ивић 1991: Павле Ивић, О Вуку Карацићу, Целокупна дела Павла Ивића, том

IV, Сремски Карловци - Нови Сад: Издавачка књижарница Зорана Стојановића.

Кашић 1987: Јован Кашић, Трагом Вукове речи, Нови Сад: Матица српска.

Милановић 2011: Александар Милановић, „Статус фонеме /џ/ у Мркаљевој реформи азбуке”, Српски језик, XVI, 127-141.

Милановић 2013: Александар Милановић, „Реформа ћирилице Луке Милованова у контексту књижевнојезичке ситуације почетком 19. века”, НССВД, 42/1, 187-197.

Николић 1968: Берислав Николић, „Белешка о овом издању”, у: Вук Стефановић Караџић, О језику и книжевности I, Сабрана дела Вука Караџића, књига дванаеста, Београд: Просвета, 389-391.

Окука 2010: Милош Окука, „Сава Мркаљ као фонолог”, Наш језик, XLI/3-4, Београд, 75-83.

Павић 1986: Милорад Павић, „Белешка о овом издању”, у: Вук Стефановић Караџић, О језику и книжевности II, Сабрана дела Вука Караџића, књига тринаеста, Београд: Просвета, 643-647.

Поповић 1987: Миодраг Поповић, Вук Стеб. Караџић: 1787-1864, Београд: Нолит.

Стевановић 1987: Михаило Стевановић, Вук у своме и нашем времену, Нови Сад: Матица српска.

Стевановић 1988: Михаило Стевановић, Од Вука до Белића и даље, Београд: Завод за уџбенике и наставна средства.

Стојановић 1924: Љубомир Стојановић, Живот и рад Вука Стеббановића Караџића, Београд - Земун: Штампарија графичког завода „Макарије” А. Д. 
Александр Миланович

\section{АКТУАЛЬНОСТЬ РАННИХ ВЗГЛЯДОВ ВУКА НА ФОНЕТИКО-ФОНОЛОГИЧЕСКИЙ СОСТАВ СЕРБСКОГО ЛИТЕРАТУРНОГО ЯЗЫКА (1814-1818)}

Резюме

Принимая с 1814 года принцип Аделунга „пиши, как говоришь”, Вук уже на первом этапе творчества много внимания посвятил инвентарю звуков и фонем в будущем сербском литературном языке. Анализ формулировок Вука при описании инвентаря фонем показал, что непосредственно перед выходом «Сербского словаря» (Српски рјечник) предложенная фонетико-фонологическая система сербского языка, по интегрированности и частотности единиц в восточно-герцеговинских говорах, имела следующую структуру: $27+1+2$. В ней частично маркирована фонема /џ/ и отдельно выделены фонемы /ф/ и /х/. Здесь заметна явная эволюция научных взглядов Вука, учитывая, что первоначальная модель из «Грамматики сербского языка» (Писменица српског језика) имела структуру $27+2$, с отдельным статусом фонем / $/$ / и / $/$ /, но без фонемы /џ/. 